\title{
Application of Granular Organic Fertilizer to Improve Yield of Red Onion
}

\author{
R.R. Rukmowati Brotodjojo ${ }^{1}$, Dyah Arbiwati ${ }^{2}$
}

\begin{abstract}
The aim of this research was to study the effect of own formulated granular organic fertilizer application on growth and yield of red onion. The experiment was arranged in a Randomized Completely Block Design. The treatment was the doses of granular organic fertilizer (10 ton/ha; 20 ton/ha; 30 ton/ha) with the control using recommended doses of inorganic fertilizers. Red onions were planted in polybags with treatment according to the experimental design, each treatment consisted of 10 polybags and repeated five times. The results showed that up to 8 weeks after planting (wap), the height of red onion did not significantly affected by the use of granular organic fertilizer or inorganic fertilizers (control). At the age of 8 wap, plants treated with granular organic fertilizer had significantly more leaves than those with inorganic fertilizers. Different doses of granular organic fertilizer did not significantly affect the number of onion leaves. Red onion treated with granular organic fertilizer significantly produced higher yield that those treated with inorganic fertilizer. This suggests that granular organic fertilizer can replace the use of inorganic fertilizer for red onion cultivation.
\end{abstract}

Keywords - granular organic fertilizer, inorganic fertilizer, red onion, yield.

\section{INTRODUCTION}

$\mathrm{R}^{\mathrm{B}}$ ED onion (Allium cepa) is considered one of high value vegetables in Indonesia. It is widely used as herb for various traditional cuisines. Red onion was cultivated in 32 provinces in the area of 122,128 ha with its production was $1,229,184$ tons in 2015 [1].

Conventional cultivation of red onion is relied on the application of inorganic fertilizers to boost production and the usage of synthetic pesticides to protect plants from pests attack. The use of inorganic fertilizers, particularly nitrogen fertilizers, continuously for long periods of time without a balanced use of organic materials has negative impact on physical and chemical properties of the soil. The decline in soil physical properties is shown by soil is compacted and reduced its porosity. The decline in soil chemical properties is demonstrated by reduced soil fertility and content of essential micro nutrients in the soil, which in turn will lower crop yields [2]. Moreover, excessive use of synthetic pesticides will lead to pests' resistance against certain pesticides and

R.R. Rukmowati Brotodjojo ${ }^{1}$ is with Universitas Pembangunan Nasional "Veteran" Yogyakarta, J1. SWK 104 Condongcatur, Yogyakarta, Indonesia

Dyah Arbiwati ${ }^{2}$ is with Universitas Pembangunan Nasional "Veteran" Yogyakarta, Jl. SWK 104 Condongcatur, Yogyakarta, Indonesia environmental contamination. In addition, the residue of pesticides could cause health problems.

To overcome the negative effects of conventional agriculture, people shift to organic agriculture that emphasis on the use of organic fertilizers as source of plant nutrients and the application of botanical or biological pesticides to overcome the interference of pests. The positive impacts of organic fertilizers application can be seen in short term and long term in improving soil fertility and yield [3-4]. Besides containing macro nutrients such as NPK, organic fertilizers also contain micro nutrients including $\mathrm{Bo}, \mathrm{Cu}, \mathrm{Fe}, \mathrm{S}, \mathrm{Zn}$ and traces of plant growth regulator. Various studies showed that growth of plant and the yield were not affected significantly by application of organic fertilizers or inorganic fertilizers. The yield of onion with the application of organic fertilizers (20 tons/ha or 40 tons/ha chicken manure or sheep manure or cattle manure) was not significantly different from those treated with inorganic fertilizers [5-6]. In addition, the content of quercetin (flavonoids) in onion bulbs was not affected significantly by the type of fertilizers, whether they were organic or inorganic fertilizers [7-8]

Agricultural waste and other organic material, including boiler ash can be processed into organic fertilizer to add nutrients to soil. Boiler ash contains macro nutrients that is essential for plant growth. It is also rich of silica that is categorized as beneficial nutrient. Nutrients content of boiler ash that resulted from combustion of bagasse for 3 hours heating time at $800{ }^{\circ} \mathrm{C}$ without oxygen feeding were $29.8 \%$ $\mathrm{SiO} 2,12.04 \%$ P2O5, 24\% K2O, 13.3\% CaO, 13.2 SO3, 1.3 $\mathrm{Mn} 2 \mathrm{O} 3,1.3 \% \mathrm{Al} 2 \mathrm{O} 3,1.8 \% \mathrm{Fe} 2 \mathrm{O} 3$ and $2.6 \% \mathrm{MgO}$ [9]. Silica improves the efficiency of photosynthesis of plants. Application of $\mathrm{Si}$ causes the leaves to grow stronger and can stretch well, so that it can reduce the negative impact of mutual shading. In addition, the existing silicate will improve plant resistance to pests and diseases [10].

The development of organic farming systems emphasizes the vitality of the plants, so plants are able to recover the damage due to pest attacks. Application of granular organic fertilizer that contains a variety of macro and micro nutrients, and enriched with boiler ash and neem leaves powder that has insecticidal properties will be able to meet most of the nutrients needed for plant growth and increase plant resistance to pests. Macro and micro nutrients contained in this organic fertilizer are available in limited quantities. Each plant needs the nutrients in different quantities, therefore, the purpose of 
this research was to study the appropriate dose for application of this granular organic fertilizer to increase growth and yield of red onion in organic cultivation.

\section{MATERIALS AND METHODS}

Red onions (Jingga, local variety) were planted in polybags (25 cm diameter; filled with $8 \mathrm{~kg}$ soil). The experiment was arranged in a Randomized Completely Block Design (RCBD) with five replications, each treatment consisted of 10 polybags. The treatments were dose of granular organic fertilizer with control treatment according to conventional cultivation using recommended dose of inorganic fertilizers.

Granular organic fertilizer used for this experiment is own formulated. Granular organic fertilizer was delivered in accordance with the treatments i.e., dose of 30 tons / ha (D1); dose of 20 ton / ha (D2); dose of 10 tons / ha (D3). For control, the plant was given inorganic fertilizers as follows: at the time of planting urea: $47 \mathrm{~kg} / \mathrm{ha}, \mathrm{ZA}: 100 \mathrm{~kg} / \mathrm{ha}, \mathrm{SP} 36$ : $311 \mathrm{~kg} / \mathrm{ha}, \mathrm{KCl}: 56 \mathrm{~kg} / \mathrm{ha}$; at two weeks after planting (wap): urea: $93 \mathrm{~kg}$ ha, ZA: $200 \mathrm{~kg} / \mathrm{ha}, \mathrm{KCl}: 112 \mathrm{~kg} / \mathrm{ha}$; at five wap: urea: $47 \mathrm{~kg} / \mathrm{ha}, \mathrm{ZA}: 100 \mathrm{~kg} / \mathrm{ha}, \mathrm{KCl}: 56 \mathrm{~kg} / \mathrm{h}$. Soil used for this study was taken from site that has not been used for conventional agricultural cultivation. The soil was sieved to be cleaned from gravel. Granular organic fertilizer was incorporated into soil at a depth of about $10 \mathrm{~cm}$ two weeks before planting. Soil was watered to field capacity every day. Red onion bulbs were planted 2 pieces per polybag. One plant that grew uniformly with others was kept per polybag after the plants were 2 wap.

Plant height and number of leaves were recorded every two weeks until eight weeks after planting. Chlorophyll content was measured using handheld Chlorophyll meter (Konica Minolta SPAD-502Plus) at 13 wap. Three leaves per plant were taken as sample for measurements. The chlorophyll meter measured the optical density of chlorophyll within two wavelength, blue $(400-500 \mathrm{~nm})$ and red $(600-700 \mathrm{~nm})$ regions. The readings showed the relative density of chlorophyll in the leaf [11]. Yield parameter were onion fresh weight/polibag, bulb diameter, number of bulb/polibag that was measured at 13 wap and economical weight that was measured after the onion kept for one week after harvesting.

\section{RESULTS AND DISCUSSION}

Vegetative plant growth can be measured from plant height and the number of leaves. This study showed that plant height of red onion at 2 wap (weeks after planting) until 8 wap did not affected significantly by the application of different dose of granular organic fertilizer (10 ton/ha; 20 ton/ha; 30 ton/ha) and the application of recommended dose of inorganic fertilizers (Tabel I). The number of onion leaves at 2 wap and 6 wap was not significantly different across treatment. However, the number of onion leaves at 8 wap was significantly affected by the type of fertilizers. Red onion treated with granular organic fertilizer significantly produce more leaves that those treated with inorganic fertilizer (Table
II).

TABLE I

Plant HeIGHT OF RED ONION (MEAN \pm SEM) (CM)

\begin{tabular}{lcccc}
\hline \hline $\begin{array}{c}\text { Fertilizer } \\
\text { Dose }\end{array}$ & 2 wap & 4 wap & 6 wap & 8 wap \\
\hline 30 ton/ha & $19,7 \pm 0,9$ a & $23,6 \pm 1,9$ a & $27,3 \pm 1,8$ a & $27,7 \pm 3,3$ a \\
20 ton/ha & $18,7 \pm 0,2$ a & $24,2 \pm 1,1$ a & $27,8 \pm 1,0$ a & $27,6 \pm 2,7$ a \\
10 ton/ha & $18,4 \pm 0,1$ a & $22,9 \pm 1,1$ a & $26,6 \pm 0,9$ a & $25,2 \pm 1,4$ a \\
Control & & & & \\
(Inorganic & & & & \\
fertilizer) & $18,7 \pm 0,8$ a & $23,0 \pm 1,7$ a & $26,0 \pm 1,6$ a & $23,8 \pm 1,7$ a \\
\hline
\end{tabular}

TABLE II

NUMBER OF LEAVES OF RED ONION (MEAN \pm SEM) (CM)

\begin{tabular}{ccccc}
\hline \hline $\begin{array}{c}\text { Fertilizer } \\
\text { Dose }\end{array}$ & 2 wap & 4 wap & 6 wap & 8 wap \\
\hline 30 ton/ha & $2,3 \pm 0,0 \mathrm{a}$ & $4,9 \pm 0,3 \mathrm{ab}$ & $8,4 \pm 0,5 \mathrm{a}$ & $12,4 \pm 1,0 \mathrm{~b}$ \\
$20 \mathrm{ton} / \mathrm{ha}$ & $2,6 \pm 0,1 \mathrm{a}$ & $5,5 \pm 0,4 \mathrm{~b}$ & $8,3 \pm 0,3 \mathrm{a}$ & $11,6 \pm 0,2 \mathrm{~b}$ \\
10 ton/ha & $2,6 \pm 0,1 \mathrm{a}$ & $4,3 \pm 0,0 \mathrm{a}$ & $8,3 \pm 0,2 \mathrm{a}$ & $10,8 \pm 0,2 \mathrm{~b}$ \\
$\begin{array}{c}\text { Control } \\
\text { (Inorganic } \\
\text { fertilizer) }\end{array}$ & $2,6 \pm 0,1 \mathrm{a}$ & $5,3 \pm 0,3 \mathrm{~b}$ & $7,5 \pm 0,8 \mathrm{a}$ & $9,6 \pm 0,5 \mathrm{a}$ \\
\hline \hline
\end{tabular}

Means in the same column followed by the same letters are not significantly different $(\mathrm{P}<0.05)$, according to Duncan Multiple Range test. wap: weeks after planting.

Nitrogen $(\mathrm{N})$, phosphorus $(\mathrm{P})$ and Potassium $(\mathrm{K})$ is a macro nutrients needed to support the growth and yield. Nitrogen is the element essential for proteins synthesis and is needed to encourage vegetative growth of plants [12]. Phosphorus plays a role in energy generation, nucleic acid synthesis, photosynthesis, glycolysis, respiration, synthesis and stability of the membrane, the activation / inactivation of enzymes, redox reactions, carbohydrate metabolism, and fixation of nitrogen (N) [13]. Potassium is an essential nutrient that affect the biochemical and physiological processes that influence plant growth and plant metabolism. Potassium also served to increase plant resistance to environmental stress, among others such as drought, salinity, pests and diseases [14]. Potassium plays a role in the activation of enzymes and helps the absorption of nutrients and water from the soil and transport assimilates from the leaf to the plant tissues [15].

In this study, apparently the differential dose of granular organic fertilizer and the type of fertilizer did not affect the height of red onion. It could be the red onion height was affected more by genetic trait. However, type of fertilizers significantly influenced the number of red onion leaves. Red onion treated with inorganic fertilizer has less leaves that those treated with granular organic fertilizer. Inorganic fertilizers provide NPK elements in sufficient quantities. On the other hand, organic fertilizer besides providing macro nutrients also provides micronutrients in lower quantities. Micro-nutrients ( $\mathrm{B}, \mathrm{Cl}, \mathrm{Cu}, \mathrm{Fe}, \mathrm{Mn}, \mathrm{Mo}, \mathrm{Ni}, \mathrm{Zn}$ ), is involved in metabolic processes in plant cells and is needed in low numbers. The 
micro-nutrients are redox-active so it acts as an active catalyst and serves as a cofactor enzyme and stabilize the enzyme activator protein [16]. Therefore, with more complete nutrient available in granular organic fertilizer, it can support the growth of red onion better than inorganic fertilizer.

TABLE III

ChLOROPHYLl CONTENT OF RED ONIONS LEAVES UNDER VARIOUS FERTILIZER TREATMENTS (MEAN \pm SEM) (SPAD VALUE)

\begin{tabular}{ll} 
Fertilizer Doses & Chlorophyll content \\
\hline 30 ton/ha & $50,4 \pm 0,9 \mathrm{ab}$ \\
20 ton/ha & $53,2 \pm 0,8 \mathrm{~b}$ \\
10 ton/ha & $47,4 \pm 1,4 \mathrm{a}$ \\
Control (Inorganic & $51,9 \pm 1,5 \mathrm{~b}$ \\
fertilizer) & \\
\hline \hline
\end{tabular}

Means in the same column followed by the same letters are not significantly different $(\mathrm{P}<0.05)$, according to Duncan Multiple Range test. SPAD Value: Index Value displayed by Konica Minolta SPAD-502Plus that reflecting the chlorophyll content in the leaf.

TABLE IV

YIELD OF RED ONIONS UNDER VARIOUS FERTILIZER TREATMENTS

\begin{tabular}{lllll}
\hline \hline $\begin{array}{l}\text { Fertilizer } \\
\text { Doses }\end{array}$ & $\begin{array}{l}\text { Fresh } \\
\text { weight/poly } \\
\text { bag }(\mathrm{g})\end{array}$ & $\begin{array}{l}\text { Economical } \\
\text { Weight/pol } \\
\text { ybag }(\mathrm{g})\end{array}$ & $\begin{array}{l}\text { Bulb } \\
\text { Diameter } \\
(\mathrm{cm})\end{array}$ & $\begin{array}{l}\text { Number of } \\
\text { bulb/polybag }\end{array}$ \\
\hline 30 ton/ha & $14,0 \pm 1,1 \mathrm{c}$ & $12,3 \pm 1,1 \mathrm{c}$ & $1,9 \pm 0,1 \mathrm{~b}$ & $2,9 \pm 0,1 \mathrm{a}$ \\
20 ton/ha & $14,3 \pm 0,2 \mathrm{c}$ & $12,5 \pm 0,1 \mathrm{c}$ & $1,6 \pm 0,1 \mathrm{~b}$ & $3,3 \pm 0,2 \mathrm{a}$ \\
10 ton/ha & $11,1 \pm 0,6 \mathrm{~b}$ & $9,2 \pm 0,5 \mathrm{~b}$ & $1,6 \pm 0,0 \mathrm{~b}$ & $3,0 \pm 0,3 \mathrm{a}$ \\
$\begin{array}{l}\text { Control } \\
\text { (Inorganic } \\
\text { fertilizer) }\end{array}$ & $6,6 \pm 0,8 \mathrm{a}$ & $5,5 \pm 0,6 \mathrm{a}$ & $1,0 \pm 0,1 \mathrm{a}$ & $3,4 \pm 0,1 \mathrm{a}$ \\
\hline \hline
\end{tabular}

Means in the same column followed by the same letters are not significantly different $(\mathrm{P}<0.05)$, according to Duncan Multiple Range test.

The chlorophyll content of plant is usually related with plant nutrient status, especially $\mathrm{N}$. The role of $\mathrm{N}$ is on the synthesis of chlorophyll, enzymes and proteins. Nitrogen is essential for the development of plant tissue $[12,17]$. This study showed that low dose of granular organic fertilizer (10 ton/ha) resulted in significantly low chlorophyll content in red onion leaves (Table III). However, the chlorophyll content was not always consistently correlated with plant yield. This study showed that the yield (fresh weight, economical yield, and bulb diameter) of red onion treated with granular fertilizer was significantly higher than those treated with inorganic fertilizer, although plant treated with inorganic fertilizer had high chlorophyll content. Plant yield is reflecting the results of photosynthesis conducted in plant leaves. The leaf area is affected by number of leaves and hereafter the capacity of the plant to conduct photosynthesis and thus the potential to form bulb [18]. When plant has more leaves, it can produce more photosynthates that are accumulated in the sink to gain yield (bulb). Therefore in this study, red onion treated with granular organic fertilizer that has more leaves also has higher yield. On the other hand, number of bulb produced per plant was not significantly affected by fertilizer treatment (Table IV). It is more likely, that number of bulb is controlled by genetic factor than nutrient status. Previous study showed that lateral shoot production and bulb splitting in shallot as the outcome of multiple growing points is determined by genetic characteristic [19].

\section{CONCLUSION}

Plant height of red onion did not affected significantly by different dose of granular organic fertilizer nor the application of inorganic fertilizer. However, red onion treated with granular organic fertilizer significantly has more leaves that those treated with inorganic fertilizer. Red onion treated with granular organic fertilizer significantly produced higher yield than those treated inorganic fertilizers. It can be suggested that the granular organic fertilizer can be used to supply nutrient in organic cultivation of red onion local variety.

\section{ACKNOWLEDGMENT}

This research was funded by The Ministry of Research, Technology and Higher Education, Republic of Indonesia through competitive grants scheme, Letter of Assignment Number: ST/30/IV/2015/LPPM. The authors would like to thank The Institute for Research and Community Services Universitas Pembangunan Nasional "Veteran" Yogyakarta for administering the grant for this study.

\section{REFERENCES}

[1] Ministry of Agriculture RI, Sub sector Horticulture, (Translated, Kementerian Pertanian RI: Sub Sektor Hortikultura: Luas panen dan produksi). http://www.pertanian.go.id/ap_pages/mod/datahorti. Accessed on 12 December 2016.

[2] H. Zhang, B. Wang, \& M. Xu, Effects of Inorganic Fertilizer Inputs on Grain Yields and Soil Properties in a Long-Term Wheat-Corn Cropping System in South China. Comm. in Soil Sci. and Plant Anals. 39, 15831599. 2008.

https://doi.org/10.1080/00103620802071721

[3] A. Granstedt, \& L. Kjellenberg, Long-Term Field Experiment in Sweden: Effects of Organic and Inorganic Fertilizers on Soil Fertility and Crop Quality. Proceedings of an International Conference in Boston, Tufts University, Agricultural Production and Nutrition, Massachusetts March 19-21, 1997.

[4] Lazcano, C., Gómez-Brandón, M., Revilla, P., \& Jorge Domínguez, J. (2013). Short-term effects of organic and inorganic fertilizers on soil microbial community structure and function - A field study with sweet corn. Biol. and Fertility of Soils 49, 723-733. https://doi.org/10.1007/s00374-012-0761-7

[5] A. Abdelrazzag, Effect of chicken manure, sheep manure and inorganic fertilizer on yield and nutrients uptake by onion. Pak. J. Biol. Sci., 5: 266-268, 2002.

https://doi.org/10.3923/pjbs.2002.266.268

[6] F. Yoldas, S. Ceylan, N. Mordogan \& B.C. Esetlili, Effect of organic and inorganic fertilizers on yield and mineral content of onion (Allium cepa L.). Afr. J. Biotechnol., 10: 11488-11492, 2011.

[7] L.M. Mogren, S. Caspersen, M.E. Olsson, \& U.E. Gertsson, Organically Fertilized Onions (Allium cepa L.): Effects of the Fertilizer Placement Method on Quercetin Content and Soil Nitrogen Dynamics, J. Agric. Food Chem., 56 (2), 361-367, 2008.

https://doi.org/10.1021/jf071813a

[8] M. Søltoft, J. Nielsen, K.H. Laursen, S. Husted, U. Halekoh, \& P. Knuthsen. Effects of Organic and Conventional Growth Systems on the Content of Flavonoids in Onions and Phenolic Acids in Carrots and Potatoes, J. Agric. Food Chem. 58, 10323-10329, 2010.

https://doi.org/10.1021/jf101091c 
[9] P. Worathanakul, W. Payubnop, \& A. Muangpet, Characterization for Post-treatment Effect of Bagasse Ash for Silica Extraction. Intl. J. Chem. Mol. Nucl. Materials and Metal. Eng. 3(8): 398-400, 2009.

[10] N. K. Savant, G. H. Korndorfer, L. E. Datnoff, \& G. H. Snyder, Silicon Nutrition and Sugarcane Production: A Review. J. Plant Nutrition 22 (12), 1853-1903, 1999. https://doi.org/10.1080/01904169909365761

[11] Konica Minolta, Chlorophyll Meter SPAD-502Plus, Manual. 2009.

[12] D.W. Lawlor, Carbon and nitrogen assimilation in relation to yield: mechanisms are the key to understanding production systems. J. Exp. Botany, 53 (370): 773-787, 2002. https://doi.org/10.1093/jxb/53.370.773

[13] C.P. Vance, C. Uhde-Stone, D.L. Allan, Phosphorus acquisition and use: critical adaptations by plants for securing a nonrenewable resource. New Phytologist 157: 423-447, 2003. https://doi.org/10.1046/j.1469-8137.2003.00695.x

[14] M. Wang, Q. Zheng, Q. Shen, \& S. Guo, The Critical Role of Potassium in Plant Stress Response. Intl. J Mol. Sci. 14: 7370-7390, 2013. https://doi.org/10.3390/ijms14047370

[15] P. Marschner, Marschner's Mineral Nutrition of Higher Plants, 3rd ed., Academic Press: London, UK, pp. 178-189, 2012.

[16] R. Hänsch, R.R. Mendel, Physiological functions of mineral micronutrients $(\mathrm{Cu}, \mathrm{Zn}, \mathrm{Mn}, \mathrm{Fe}, \mathrm{Ni}, \mathrm{Mo}, \mathrm{B}, \mathrm{Cl})$. Current Opinion in Plant Biol. 12 (3): 259-266, 2009. https://doi.org/10.1016/j.pbi.2009.05.006

[17] R.A. Bungard, A. Wingler, J.D. Morton, M. Andrews, Ammonium can stimulate nitrate and nitrite reductase in the absence of nitrate in Clematis vitalba. Plant Cell Environ., 22: 859-866, 1999. https://doi.org/10.1046/j.1365-3040.1999.00456.x

[18] J. E. Lancaster, C. M. Triggs, J. M. De Ruiter \& P. W. Gandar, Bulbing in Onions: Photoperiod and Temperature Requirements and Prediction of Bulb Size and Maturity, Annals of Botany 78: 423-430, 1996. https://doi.org/10.1006/anbo.1996.0138

[19] B.T. Steer, The bulbing response to day length and temperature of some Australian cultivars of onion (Allium cepa L.). Aust. J. Agri. Res., 31: 511-518, 1980. https://doi.org/10.1071/AR9800519

R.R. Rukmowati Brotodjojo got her Bachelor degree from Faculty of Agriculture, Gadjah Mada University, Indonesia in 1989. Her major field of study is plant protection. She acquired her Master degree in Agricultural Entomology from The University of Sydney, Australia in 1998 and obtained her PhD in Entomology from The University of Queensland, Australia in 2007.

She is an associate professor in the Faculty of Agriculture, Universitas Pembangunan Nasional "Veteran" Yogyakarta (UPNVY), Indonesia. She worked as research fellow at the University of Queensland under Endeavour Award granted by the Department of Education, Employments and Workplace Relations, Australia in 2009-2010. Her research interest are biological control and sustainable agriculture.

Dr. R.R. Rukmowati Brotodjojo is a member of The Entomological Society of Indonesia. She got An Outstanding Lecturer award from UPNVY in 2010 .

Dyah Arbiwati obtained her Bachelor degree in Soil Sciences from Faculty of Agriculture, Universitas Pembangunan Nasional "Veteran" Yogyakarta (UPNVY), Indonesia in 1988. She majored in Soil Sciences. She got her Master degree in Soil Sciences from Gadjah Mada University, Indonesia in 2000.

She is a senior lecturer in the Faculty of Agriculture, Universitas Pembangunan Nasional "Veteran" Yogyakarta (UPNVY), Indonesia. Her research interest is management and improvement of soil fertility. Mrs. Dyah Arbiwati is a member of The Indonesian Society of Soil Science. 